\title{
Research and Reference on Professional Ethics Development of American College Teachers
}

\author{
Ya Kong \\ Qufu Normal University \\ Qufu, China
}

\author{
Yuan Kong* \\ Jining Medical University \\ Jining, China
}

\begin{abstract}
With the development of market economy, the change of social and economic structure, the complexity of social interests, the decline of social morality, especially the decline of professional morality of University teachers. Naturally, there are many reasons for this contradiction, but the weak practice of professional ethics of college teachers is one of the important reasons. As the earliest country in the world, the United States has obvious characteristics in the content source and formation of teacher ethics norms. From the perspective of American educational circles, the professional ethics of university teachers is not only reflected in the relationship between teachers and students, teachers and colleagues, but also in the attitude of teachers towards profession and academia. Studying the construction of teachers' professional ethics in the United States is of great significance for us to promote the construction of teachers' professional ethics.
\end{abstract}

Keywords-America; Professional Ethics of College Teachers; Norms; Enlightenment

\section{INTRODUCTION}

Teachers are an ancient profession of human beings. In the long-term educational practice, some ethical and moral requirements about this profession have been accumulated. Nevertheless, in the past, although people had some understanding of the particularity of teachers' profession, they also paid attention to the difference between teachers' professional ethics and general professional ethics, and paid great attention to the importance of teachers 'professional ethics. However, since teachers' profession was not regarded as a profession, the construction of teachers' professional ethics mainly stayed in the construction of teachers' professional ethics. General personal moral level. With the advancement of teachers' professionalization movement, teachers are required not only to improve their basic quality but also to have professional ethics matching their professional profession, showing the professional service spirit that professionals should have.

According to the general understanding, professional ethics refers to the self-restraint behavior norms formulated by professional groups to better fulfill their professional responsibilities, meet social needs and maintain their professional reputation [1]. Macroscopically speaking, there is no essential difference between professional ethics and other

This paper is sponsored by Scientific Research Support Fund for Teachers of Jining Medical University (Grant No. JYFC2018RW020); An Industry-University Cooperative Project of Ministry of Education (Grant No. 201801200014); The Visiting Scholar Funded Program of Young Backbone Teachers in Jining Medical University

Corresponding author: Yuan Kong, Email: kongy_1116@163.com professional ethics. They are moral restraints imposed on members of the industry in order to maintain their reputation and protect its interests under the conditions of the social division of labor. However, there are at least two differences between professional ethics and general professional ethics because of the difference between profession and general profession: first, the scope of action is different, the scope of action of general professional ethics is wide, and professional ethics only works within the scope of profession; second, the mechanism of action is different, and the practice of professional ethics mainly depends on the ethics of professionals. Self-discipline, by contrast, is easier to accept the restraint of heteronomy. Besides, the two depend on different foundations. The general professional ethics depends more on experience. Professional ethics must be supported by professional knowledge and technology. Without professional knowledge and technology, the behavior will be reckless and even harm the life or society to be treated.

For University teachers, professional ethics should be the primary and basic requirement for the professionalization of University teachers. As Goodson pointed out, "Teaching is first and foremost a moral and ethical profession, and the new professionalism needs to be reiterated as a guiding principle"; "In the new teaching ethics, professionalism and professionalism should be reiterated." It will be unified around the moral definition of teaching and students' learning. It can be seen that professional ethics is an indispensable part of the profession, an important symbol of professional maturity, and therefore an important dimension to promote teachers' professionalization [2].

The United States is one of the earliest countries in the world to formulate and implement professional norms for teachers. It has a distinctive and systematic construction system of professional ethics for University teachers. To sort out and analyze the historical process and content of the construction of American college teachers' professional ethics can provide us with useful enlightenment.

\section{The Course of Professional Ethics Construction OF AMERICAN COLLEGE TEACHERS}

The construction of teachers' professional ethics in American colleges and universities is embodied in the construction of teachers' professional ethics as a whole, which follows the general norms of teachers' professional ethics construction. By reviewing the historical process of the construction of American teachers' professional ethics, we can 
provide a reference for the perspective of the construction of American teachers' professional ethics. The construction of American teachers' professional ethics began in the colonial period. At that time, church staff such as priests were still the main source of American teacher groups. The church or government issued a series of teacher management decrees, which stipulated that all teaching staff must hold the license issued by the church or the government, and should be familiar with the Bible and be skilled in answering questions and actively disseminate doctrines and cultural knowledge. Knowledge. To this end, the church or the governmentappointed special personnel to examine the qualifications of teachers, manage, supervise and evaluate teachers' educational and teaching activities, and put forward strict and clear requirements and norms for teachers' professional ethics. For example, Massachusetts, which was the earliest state to have public education, enacted the main contents of Teacher Education in the form of statutes as early as 1642, including knowledge of criminal law, belief in God, reading and writing skills, etc. In 1654, a special decree was promulgated, regarding religious faith as an important criterion for the qualification examination of teachers, emphasizing that "people who are not faithful, misbehave and violate the teaching rules should not be employed to undertake the duties of college teachers and to teach young people. If there are teaching staff who are not suitable for the above requirements, they should be dismissed" Teachers who oppose professional ethics are fined or even dismissed [3].

After the War of Independence, with the rapid development of capitalist economy, the demand for the quantity and quality of teachers in American society has been expanding day by day, which puts forward higher requirements for the level of teachers' professionalization (including professional ethics), and gives birth to the theory and practice of teachers' professionalization development in the United States. Many professional colleges and comprehensive universities have established teacher training schools or teacher education colleges focusing on teacher professional training. The government has begun to explore the establishment of a more perfect teacher management system, while schools have incorporated teacher professional and professional training into their own construction. Thus, the management mode of teachers' professional ethics, which is coordinated and autonomous at different levels, has been formed and promoted the institutionalized development of teachers' professional ethics construction in the United States. In 1875, the National Association of Teachers was founded in Philadelphia, and then the National Association of Education was established on the basis of the Association of School Supervisors and the Association of Teachers' Schools. Once established, the two associations assumed the important task of formulating and promulgating national norms for teachers' profession, and initiated the historical process of building teachers' professional ethics by relying on teachers' profession organizations. In 1896 , the Georgia Teachers' Association, the affiliated organization of the National Teachers' Association of the United States, formulated and promulgated the world's earliest professional ethics code for teachers, the Professional Ethics Code for Teachers, which systematically stipulated the ethical requirements of teachers' practice and pioneered the formulation of professional ethics by teachers' professional organizations [4].

In the 20th century, the United States began a systematic study of teachers' moral qualities. Among them, the research results on teachers' personality quality are the most abundant. In the 1920s and 1930s, Katas and Webers used empirical methods to systematically analyze and summarize 25 personality traits and behavioral characteristics that excellent teachers should possess. Most of them are related to teachers' professional ethics, which has a wide impact on the construction of American teachers' professional ethics. In 1929, the National Association of Education first formulated a national code of professional ethics for teachers, the Code of Teaching Ethics, which stipulates the basic professional ethics of teachers, especially teaching ethics, and highlights the importance of morality to teachers' professional activities. Since then, the code has been revised three times in 1941, 1952 and 1963, and the principles of teachers' professional ethics have been refined, especially in clarifying the scope of application of the norms, clarifying the boundaries of the norms' responsibilities, and the general requirements of previous directives and principles have been refined into specific norms of prohibition and regularity. At the end of the 1960s, influenced by the "arms race" and progressive educational thoughts of the two superpowers of the United States and the Soviet Union, the construction of teachers' professional ethics was put in a more important position. On the basis of social orientation, the student dimension was highlighted. It was emphasized that it was important to measure teachers' professional ethics whether they could serve students' development and improve students' innovative ability Standards. In this case, the Code of Teaching Ethics has revised again in 1968 and renamed as the Code of Ethics for Educational Specialty, which is known as the NEA Code. From the two dimensions of students and society, the code specifies in detail the moral responsibility of teachers for students' growth and social development and the ethical norms they follow. Since then, the code has undergone two revisions in 1975 and 1986 [4]. It further divides the professional ethics of teachers into two parts: "devoted students" and "devoted profession", and specifies the specific requirements of each part in detail, making it the most authoritative policy basis for the construction of teachers' professional ethics in the United States. According to.

Generally speaking, the construction of American teachers' professional ethics (including the construction of University teachers' professional ethics) has undergone three levels of development and transformation in the course of more than two hundred years. First, in terms of value orientation, it has undergone a transformation from a single social dimension to a "social-student" dual dimension. From the colonial period to the 19th century, the United States relatively highlighted the value priority of society in the construction of teachers' professional ethics, emphasizing the social function of teachers' professional ethics in maintaining social spiritual order and promoting the development of capitalist economy. In the late 19th century, Parker, the father of American progressive education, put forward the idea that "education should adapt schools to students, not students to schools" in the "Quincy 
Educational Reform Movement", which marked that progressive education theory began to become an important guideline for the development of American educational reform. Under the guidance of this idea, the construction of American teachers' professional ethics in the past hundred years has risen again and again, with the principle of respecting students' principal status and the goal of building democratic and equal teacher-student relationship. Secondly, in terms of concrete content, it has undergone a transformation from scattered experience to system science. Early American teachers' professional ethics construction mainly centered on specific social needs and educational objectives. Teachers' professional ethics requirements in various states and schools were relatively scattered, and most of them were the summary of local school experience. Later, with the rapid development of pedagogy and psychology and the involvement of scientific research institutions in Colleges and universities, the United States began to explore the content system of teachers' professional ethics construction with universal binding force, applicability and professional pertinence. Thirdly, in practice, it has undergone a transformation from government-led, statutory regulation to industry association-led and normative restraint. Early American teachers' professional ethics construction (mainly in the colonial period) was a compulsory ethical regulation of teachers' groups through the enactment of laws and regulations by the government [5]. Later, with the reform of education system, the rapid development of private schools, especially the establishment of teachers' professional associations, the construction of teachers' professional ethics previously controlled by the government was carried out. The power began to be gradually transferred to the teachers' professional associations, and the way of standardization was also changed from the previous statutory regulation to the industry restriction.

\section{CONTENTS OF PROFESSIONAL ETHICS OF AMERICAN COLLEGE TEACHERS}

From the perspective of American educational circles, the professional ethics of university teachers is not only reflected in the relationship between teachers and students, teachers and colleagues, but also in the attitude of teachers towards profession and academia due to the characteristics of the profession of University teachers.

\section{A. Teacher-student relationship: "respect" and "equality"}

The relationship between teachers and students is the core of University teachers' working relationship. The responsibility of American college teachers is to "believe in the value and dignity of every student, help every student realize his inherent potential as a valuable and effective member of society, and cultivate students' democratic beliefs". In 1975, the Code of Ethics of the American Educational Association clearly stipulated that teachers should not unreasonably restrict students' independent activities in school, prevent students from contacting different views, deliberately conceal or distort materials related to students, and make every effort to protect students' learning, health and well-being. Safety should not be harmed; students should not be deliberately embarrassed or belittled; students should not be unfairly excluded from any course, deprived of any student's interests, given any student any post on the basis of race, sex, nationality, marital status, political concept, family, social and cultural background or gender orientation. What favorable conditions; not to use the professional relationship with students for personal gain; not to disclose the personal information of students obtained in the course of their career, unless it is based on the necessary professional intentions or legal needs [6].

It can be seen that the professional ethics of teachers in American colleges and universities does not put forward the general principle of the teacher-student relationship, but puts forward how teachers treat their students and their obligations to students, which reflects the specific requirements of teachers to respect students' personality and treat students equally and fairly. According to these rules, it is easier to judge whether the teacher's behavior violates the rules, so as to facilitate the supervision of the surrounding public opinion. Moreover, teachers' professional ethics also includes teachers' self-interest in avoiding their functions and powers. It will affect teachers' attitudes and evaluation of students, the impact on students' growth, and has a special significance in preventing "teacher corruption". The reason for this is that American higher education is based on adapting to the needs of students to build a university teaching and management system. The curriculum system of American universities is essentially elective-based. Students can choose not only courses, but also teachers, majors and even schools. This puts forward higher requirements for the academic level, teaching level and moral accomplishment of University teachers.

\section{B. Teacher-colleague Relations: "Collaboration" and "Respect"}

According to a survey conducted by the US Department of Education, when teachers can exchange ideas with each other, cooperate in activities and help each other, students' unions can benefit greatly. In the teaching practice of colleges and universities, teachers can exchange and cooperate in many aspects, such as the design of evaluation tools, the selection of textbooks or other teaching materials, the design of interdisciplinary learning units, and the cooperative research of scientific research projects. Through these exchanges and cooperation, teachers can learn a lot from their colleagues, broaden their thinking, so as to improve their professional level.

In the process of communication, teachers should also try to exclude all kinds of acts that violate the dignity of the other party and affect cooperation, and the norms are very specific. For example, Minnesota's rules concerning teacher-colleague relationships include: teachers are not allowed to use their colleague relationships for personal gain, and they are not allowed to distort materials and facts about other teacher qualifications. Teachers' criticisms of colleagues' performance and related work are carried out face to face rather than in private, and only when they inform their colleagues of such intentions in writing can they convey such criticisms to the appropriate persons who can provide advice and help. The Code of Ethics of the American Educational Association also expressly stipulates that when colleagues apply for educational posts, they cannot make false statements about their professional qualifications; they cannot help non-educators to 
engage in educational activities of an unqualified level; they cannot disclose personal information of their colleagues obtained in the course of their careers, unless it is based on the necessary professional intentions or otherwise. Need of law; not deliberately belittle or maliciously slander colleagues. For example, the American Professors Association has made the following provisions on the relationship between teachers and colleagues: as a peer, a professor should respect and protect his colleagues' freedom of academic inquiry; when exchanging and commenting on opinions, he should show respect for others' opinions, strive to treat peer evaluation objectively and share learning. Teachers' responsibilities in school management [7].

It can be seen that mutual respect for personality and reputation, respect for colleagues' opinions and suggestions, protection of colleagues' privacy, communication and collaboration, and sharing of responsibilities are the basic principles of dealing with colleague relations in the professional ethics of American University teachers. This is the weakest link in the construction of teachers' professional ethics. For the relationship between teachers and colleagues, we only propose "solidarity and cooperation" to be involved. It can be seen that, starting from the characteristics of the teachers' profession, it is of great significance to establish the basic norms of the relationship between teachers and colleagues.

\section{Teachers' Attitudes towards Profession: "Honesty" and "Enterprising"}

The attitude of university teachers towards the profession is an important link in the construction of teachers' professional ethics, which directly affects how teachers deal with the relationship with students and colleagues. In 1975, the Code of Ethics of the American Educational Association clearly pointed out: "The quality of education service will directly affect the whole nation and its people. Based on this idea, educators should do their utmost to improve such a standard and form such an atmosphere as encouraging correct professional judgment, attracting trustworthy people to engage in educational undertakings in a good atmosphere, and helping to prevent unqualified people from carrying out educational practice. At the same time, it is stipulated that, as a teacher, we should not intentionally make wrong statements in applying for educational posts, nor produce false materials related to competence and qualification, nor misinterpret personal professional qualifications and professional conditions, nor assist anyone who is unqualified in personality, education or other related qualities. Become a professional educator; do not accept any gifts, gifts or favors that may weaken or affect career decisions or actions. In addition, almost all the Handbooks of teachers and students in American universities contain specific annotations and regulations on academic integrity. Many universities have also formulated regulations on academic reputation.

American educational circles also believe that students are not the only learners in Colleges and universities. Teachers should also regard themselves as learners and personal initiative and career development as personal responsibilities. Because without the improvement of teachers' quality of life, it is difficult to have high quality of education; without teachers' active development, it is difficult to have students' active development; without teachers' educational creation, it is difficult to have students' creative spirit. Only when teachers consciously improve themselves can they be more conducive to the improvement and development of students [8]. Therefore, the pursuit of truth, academic freedom and endless learning have become widely accepted professional beliefs of American College teachers. Article 1 of the American Professors' Association's Code of Ethics stipulates that "in order to safeguard the dignity of advanced knowledge, professors should be aware of their special responsibilities. Professor's basic responsibility in his major is to explore and clarify the truth he has discovered. Therefore, he should devote all his energy to develop and improve his academic ability, and constantly exercise his self-criticism and judgment ability in the application, expansion and dissemination of knowledge. Professors should abide by the honesty of intellectuals and never allow other interests to hinder or impair the freedom to explore knowledge."

\section{CONCLUSION}

College teachers' professional ethics plays an important role in the long-term development of the country, nation and society. Therefore, in order to promote the construction of teachers' professional ethics in Colleges and universities, we must attach great importance to the professionalism and particularity of modern educational professional labor. According to the regular requirements of the development of the educational profession and combining with the specific practice of educational professional activities, we should critically absorb the experience of the research and practice of American teachers' professional ethics, so as to make more benefits for each other. The stakeholders participated in the discussion of the construction of University teachers' professional ethics, and actively constructed the system of University teachers' professional ethics conforming to their own national conditions.

\section{A. Stimulating the enthusiasm of teachers' professional organizations and Universities}

As mentioned above, the construction of teachers' professional ethics in American colleges and universities pays attention to the participation of multiple subjects, especially to give industry organizations and universities greater autonomy, by which they formulate teachers' professional ethics policies according to their own conditions. Specifically, we should strive to stimulate the enthusiasm and initiative of teachers' professional ethics organizations and universities in various places, and constantly improve the main structure of the policymaking of teachers' professional ethics in Colleges and universities. To this end, first of all, we need to clarify the responsibilities, mainly the responsibilities of the education authorities at all levels of macro-planning, direction grasp, policy consultation and internal restraint of various types of teachers' organizations, and the responsibilities of universities to refine policies and implement them. Secondly, according to the division of responsibilities, teachers' professional organizations and universities should be empowered accurately, and they should be allowed to actively explore flexible disposal 
mechanisms and specific implementation plans suitable for their own industries and schools under the unified norms of national policies.

\section{B. Attracting more stakeholders to participate in the discussion}

Teachers' professional ethics in the United States is directed at the whole education industry. Besides NEA, there are also some specific norms in the scope of NPA's Psychologist Ethics Code and American Professor's Ethics Statement. These are through the industry, so that more education stakeholders participate in case interviews, research and other practical activities, collected more data, to provide evidence for teachers' professional ethics. Therefore, the education sector or the education industry can initiate relatively large practical research, so that more stakeholders can participate in the discussion of the construction of teachers' professional ethics which is related to the development of the country and the prosperity of the nation, rather than the voice of a few educators. College teachers' professional ethics in line with their own national conditions can gain public trust, but also provide practical guidance for teachers, which is conducive to the growth of this team.

\section{Strengthening the Ethical Role Consciousness of College Teachers}

College teachers are the unity of the two social roles of educators and researchers. Their roles have different requirements in different countries. A prominent feature of American college teachers' professional ethics construction is to stimulate and guide their ethical role consciousness in accordance with their own economic and social development needs and ideological characteristics, and to penetrate all kinds of teaching activities, giving teaching activities a distinct moral orientation. College teachers, as educators, shoulder the responsibility of training social talents, and should follow the political ethics of patriotism and patriotism. College teachers, as researchers, shoulder the responsibility of providing intellectual support for economic and social development, and should follow the scientific research ethics of pursuing truth and serving the society. Among them, political ethics is the foundation, teacher ethics is the foundation, and scientific research ethics is the guarantee. The three are unified in the role of social ethics of University teachers, which is embodied in the practical activities of teacher education, teaching, scientific research, social service, cultural heritage and innovation. To enhance the ethical role consciousness of University teachers, the key is to enhance their political ethics, scientific research ethics and ethics of teachers, so that they can truly become adherents to social justice, pioneers in the forefront of scientific research, and consciously fulfill the mission of teaching and educating people.

\section{Strengthening the Professional Construction of College Teachers' Professional Ethics}

On the basis of listening to different voices, it is very important to strengthen the professional construction of College teachers' professional ethics. The construction of the professional ethics of university teachers mainly emphasizes teachers' professional competence and quality. Professional competence is the knowledge capital of teachers. Professional accomplishment is to promote the free and all-round development of every student on the premise of justice, fairness and humanity, starting from the characteristics of educational specialty and focusing on the development of the interests of educational service objects. This is also the essence and fundamental ethical demand of education. Therefore, we should improve teachers' professional organizations at different levels, give full play to the role of the main body of teachers' organizational construction in the formulation of professional ethical norms, effectively establish relatively unified and professional teachers' ethical norms, enhance the autonomy and rights-safeguarding consciousness of teachers' professional associations, and strive to realize the transformation of educational professional norms from administrative orders to professions. The change of rules and regulations will realize the active change from "heteronomy" to "self-discipline" of teachers.

\section{E. Paying attention to the hierarchy and operability of the professional ethics of University Teachers}

In the course of its revision, the NEA Guidelines of the United States have repeatedly emphasized its specificity and operability. We can draw lessons from this and construct a hierarchical system of professional ethics for University teachers. Without beautifying the profession of teachers as clergy, there should be double stipulations and respect of duties and rights in the complete professional ethics of University teachers. The violation of ethics beyond this norm is no longer applicable to the professional ethics of University teachers. Only in this way can the public's expectation of teachers' personality return to rationality, and improve the public's basic trust and appropriate expectation of university teachers and their professions. At the same time, we should pay attention to advocating the pursuit of "teachers' professional ethics ideal" and "the best human nature". Because norms can make work orderly, and morality can make individuals noble. We should also pay attention to the correct orientation of "teachers' professional ethics ideal". It is not worth advocating that teachers should always focus on students, regardless of their children's growth.

\section{REFERENCES}

[1] Elizabeth Campbell, The Ethical Teacher. Maidenhead, UK: Open University Press McGraw-Hill.

[2] Elizabeth Campbell "The Ethics of Teaching as a Moral profession”, curriculum Inquiry, Vol. 38. 2008.

[3] Journal of Moral Education, Vol. 22, 1993

[4] J.I. Goodlad, R. Soder, \&K.A. Sirotnik (eds.) The Moral Dimensions of Teaching, San Francisco: Jossey-Bass, 1990.

[5] K.A. Strike, J.F. Soltis, The Ethics of Teaching, New York: Teachers College Press, 1992

[6] V. Richardson, G. D. Fenstermacher, Mannerin Teaching: the study in Four Parts, Journal of Curriculum Studies, Vol. 33, 2001.

[7] D.T. Hasen, “Teaching as a Moral Activity”, In V. Richardson (ed.), Handbook of Research Teaching, Washington. DC: American Educational Research Association, 2001.

[8] Tenure Track Handbook for Faculty of Art and Sciences, Harvard University, 2013-2014. 